\title{
UJI FUNGSI RADIOGRAFI SINAR-X DI HOT CELL INSTALASI RADIOMETALURGI
}

\section{FUNCTION TEST OF X-RAY RADIOGRAPHY IN A HOT CELL OF RADIOMETALURGY HOT LABORATORY}

\author{
Helmi Fauzi ${ }^{1}$, Refa Artika $^{2}$, Setia Permana ${ }^{3}$, Antonio Gogo ${ }^{4}$ \\ ${ }^{1234}$ PTBBN-BATAN Kawasan Puspiptek Ged.20 Serpong 15310 \\ Email: helmi@batan.go.id
}

Diterima: 8 Oktober 2019, diperbaiki: 21 Oktober 2019, disetujui : 23 Oktober 2019

\begin{abstract}
ABSTRAK
UJI FUNGSI RADIOGRAFI SINAR-X DI HOT CELL INSTALASI RADIOMETALURGI. Radiografi sinar-X telah dipasang di hot cell 103 dari Instalasi Radiometalurgi (IRM) yang digunakan untuk pemeriksaan Pelat Elemen Bakar (PEB) dan short pin PWR-fuel teriradiasi. Radiografi sinar-x merupakan sebagian dari keseluruhan data uji pasca iradiasi yang diperlukan untuk investigasi unjuk kerja dari bahan bakar nuklir yang sangat dibutuhkan di IRM.Tabung sinar-X yang digunakan dengan tegangan $20-320 \mathrm{kV}$ dan flat panel detector serta meja objek uji yang dapat bergerak ke arah longitudinal dan transversal. Gerak vertikal (pengaturan jarak tabung ke objek) dilakukan secara manual dengan manipulator. Sistem dukung yang terdiri dari unit trafo, pendingin dan panel terpasang di service area sedangkan unit pengendali berupa komputer terpasang di operating area. Uji fungsi dilakukan dengan variasi beberapa parameter operasi. Uji fungsi berhasil dilakukan menggunakan PEB teriradiasi dengan resolusi yang baik, dimana batas cladding dan meat dapat terlihat dengan jelas, dengan parameter utama $200 \mathrm{kV}$, $800 \mu \mathrm{A}$ dan integration time $130 \mathrm{~ms}$. Hasil digital radiografi untuk short fuel pin PWR belum baik sehingga masih membutuhkan studi dan eksperimen lebih lanjut untuk menentukan parameter operasi. Hal ini terkait adanya perbedaan koefisien atenuasi sinar- $\mathrm{X}$ antara $\mathrm{U}$ dan $\mathrm{Zr}$.
\end{abstract}

Kata kunci: radiografi sinar-X, hot cell, Instalasi Radiometalurgi, uji pasca iradiasi

\section{ABSTRACT}

FUNCTION TEST OF X-RAY RADIOGRAPHY IN A HOT CELL OF RADIOMETALURGY HOT LABORATORY. X-ray radiography installed in hot cell 103 of Radiometalurgy Hot Laboratory for irradiated nuclear fuel plate type and short pin PWR-fuel. This radiography used 20-320 kV of the x-ray source and flat panel detector and removable sample table for longitudinal and transversal. Vertical movement (to adjust the distance between $x$-ray source tube and object) adjusted manually by manipulator. The supporting units such a high voltage unit, cooling unit and panel unit installed at the service area while the computer as control unit installed at the operating area. Function test is carried out with variations of several operating parameters. The function test was successfully performed using irradiated PEB with good resolution, where the cladding and meat limits can be seen clearly, with the main parameters $200 \mathrm{kV}, 800 \mu \mathrm{A}$ and 130 ms integration time. The results of digital radiographs for short pin PWR-fuel still need further studies and experiments to determine operating parameter according to different $x$-ray attenuation coefficients between $\mathrm{U}$ and $\mathrm{Zr}$.

Keywords: X-ray Radiography, hot cell, Radiometalurgy Hot Laboratory, post irradiation examination 


\section{PENDAHULUAN}

Pengelolaan fasilitas laboratorium termasuk fasilitas laboratorium uji pasca iradiasi dari Instalasi Radiometalurgi (IRM) dibawah Bidang Uji Radiometalurgi (BUR) dari Pusat Teknologi Bahan Bakar Nuklir. BUR mempunyai tugas melaksanakan pengelolaan fasilitas uji pasca iradiasi berupa hot cell dan pengembangan teknik uji radiometalurgi, dengan satu dari rincian tugasnya yaitu: melaksanakan pengembangan teknik uji tak merusak bahan struktur dan bahan bakar nuklir ${ }^{[1]}$. IRM dimanfaatkan untuk melaksanakan program pemeriksaan dan pengujian pasca iradiasi untuk mengetahui kondisi unjuk kerja dari elemen bakar nuklir dan komponen reaktor $^{[2]}$.

Pada program renstra PTBBN 20152019 untuk program revitalisasi fasilitas hot cell IRM telah direncanakan untuk menggunakan radiografi sinar- $X$ yang akan ditempatkan di hot cell 103. Persiapan sudah mulai dilakukan terkait spesifikasi, anggaran dan juga termasuk dekontaminasi hot cell 103, yang sudah dimulai dari tahun 2014 , dan pada tahun 2017 sudah dinyatakan aman untuk intervensi personel ke dalam hot cell 103. Hal ini harus disiapkan karena instalasi peralatan di dalam hot cell dilakukan langsung oleh personel BUR.

Data "visual" dari bahan bakar nuklir pasca iradiasi dapat diperoleh dengan menggunakan radiograf sinar- $X$, yang merupakan salah satu informasi penting, serta merupakan sebagian dari keseluruhan data yang diperlukan untuk mengetah unjuk kerja dari bahan bakar nuklir tersebut. Pengukuran dimensi dari objek uji dapat dilakukan dengan menggunakan radiograf sinar-X dengan faktor koreksi tertentu, perolehan diameter pin, pellet-clad-gap, pellet-topellet gap, kompresi pegas pada ruang plenum, batas meat dan cladding pada elemen bakar pelat, serpihan pellet, cacat pada cladding dan lain sebagainya. Perolehan data awal "visual" ini dapat dikonfirmasikan dengan data uji tak merusak lainnya seperti, pengukuran dimensi untuk mengetahui apakah ada perubahan dimensi dibandingkan dengan data pra iradiasi, data hasil perekaman secara visual (fotografi), gamma scanning, Ultrasonic Testing (UT), Eddy Current (EC) atau metoda NDT lainnya.

Sebagai fasilitas yang didesain untuk menyajikan data uji pasca iradiasi dari bahan bakar nuklir atau komponen reaktor lainnya pasca iradiasi, pihak pengelola laboratorium dari Instalasi Radiometalurgi (IRM) telah berencana untuk mempunyai fasilitas radiografi sinar-X di hot cell 103, sebagai pengganti sistem sinar- $X$ sebelumnya yang masih menggunakan film. Pada kegiatan di tahun 2018, telah berhasil diinstal radiografi sinar-X di hot cell 103 beserta sistem pendukungya. Pada tulisan ini hendak dibahas tentang alat radiografi sinar-X yang telah terpasang di hot cell 103 IRM yang meliputi informasi tentang deskripsi alat serta kemampuannya sehingga diharapkan dapat dimanfaatkan untuk litbang bahan bakar nuklir atau material yang telah teriradiasi lainnya.

\section{DASAR TEORI}

Radiografi sinar-X dapat digunakan terhadap bahan bakar nuklir pasca iradiasi yang merupakan salah satu metoda untuk mengetahui unjuk kerja bahan bakar nuklir tersebut. Tingkat kesulitan yang dihadapi bila dibandingkan dengan penggunaan radiografi sinar- $X$ pada umumnya yaitu, radiografi sinar-X terhadap objek berupa bahan bakar nuklir pasca iradiasi tersebut memancarkan radiasi gamma dan juga sinar-X. Besaran energi sinar-X dari bahan bakar nuklir teriradiasi sampai dengan 123,1 keV[3]. Dengan demikian 
maka dimensi atau tebal dari bahan bakar nuklir pasca iradiasi tidak menentukan besaran energi sinar- $X$, seperti pada penggunaan radiografi sinar-X untuk objek non iradiasi, tetapi besar energi sinar-X lebih ditentukan oleh energi sinar-X yang dipancarkan dari objek uji berupa bahan bakar nuklir teriradiasi.

Penggunaan objek berupa bahan bakar pasca irradiasi pada pencitraan sinar-X untuk divisualkan, bukanlah hal yang mudah karena adanya radiasi gamma dan penggunaan perisai radiasi. Tiga masalah utama yang dihadapi adalah:

- Terkait radiografi, jumlah sinar-X dari bahan bakar pasca iradiasi dapat mengganggu jumlah sinar- $X$ yang dihasilkan oleh sumber yang digunakan untuk pencitraan (yaitu tabung sinar-X). Hal ini dapat berpengaruh terhadap hasil radiograf sehingga dapat berpengaruh juga terhadap hasil analisis data 2D atau rekonstruksi 3D.

- Radiasi gamma dan sinar-X dari bahan bakar teriradiasi dapat merusak sistem deteksi serta sumber sinar-X. Selain itu juga harus dipertimbangkan radiasi latar yang dihasilkan oleh lingkungan di dalam hot cell. Penggunaan pelindung mekanis dapat dipertimbangkan.

- Optimalisasi sumber sinar-X dan pengaturan detektor dengan kolimator yang sesuai akan membantu mengurangi efek gangguan.

- Penggunaan timbal dapat diterapkan pada detektor dan bagian peralatan yang sangat sensitif lainnya.

Terkait permasalahan tersebut di atas, diperlukan spesifikasi tertentu Radiografi Sinar-X untuk kebutuhan pengujian PEB dan short pin PWR-fuel pasca iradiasi.
Pada tulisan ini menjelaskan tentang radiografi sinar-X yang terpasang di hot cell 103 IRM yang dapat digunakan untuk radiografi bahan bakar pasca iradiasi, baik berupa Pelat Elemen Bakar (PEB) maupun short pin PWR-fuel.

\section{METODOLOGI}

Setelah instalasi dan pemasangan Radiografi Sinar-X dilakukan, maka pengoperasian dan uji coba dapat dilakukan untuk menentukan parameter operasi menggunakan PEB non-iradiasi. Berikutnya dilakukan uji fungsi dengan objek uji berupa PEB teriradiasi. Objek uji tersebut merupakan sampel dari litbang bahan bakar tingkat muat Uranium tinggi $(4,8 \mathrm{~g} / \mathrm{cc})$ yang telah diiradiasi di Reaktor Serba Guna GA Siwabessy (RSG-GAS), kemudian dibawa ke hot cell 103 IRM melalui Kanal Hubung Instalasi Penyimpan Sementara Bahan Bakar Bekas (KH-IPSB3).

Objek uji lainnya berupa short pin $P W R$-fuel non-iradiasi dan sampel pelat aluminium dengan cacat tertentu. Pada setiap objek uji tersebut dicarikan parameter operasi yang optimum sehingga dapat menghasilkan citra digital radiograf yang lebih baik.

Sistem Radiografi Sinar-X menggunakan flat panel detector dengan meja objek uji yang dapat digerakkan ke arah Yo (longitudinal) dan Xo (transversal) dari komputer pengendali di operating area serta Zo (vertical) secara manual dengan manipulator (Gambar 1). Sistem pendukung seperti unit tegangan tinggi (trafo), unit pendingin dan panel berada di service area (Gambar 2). 


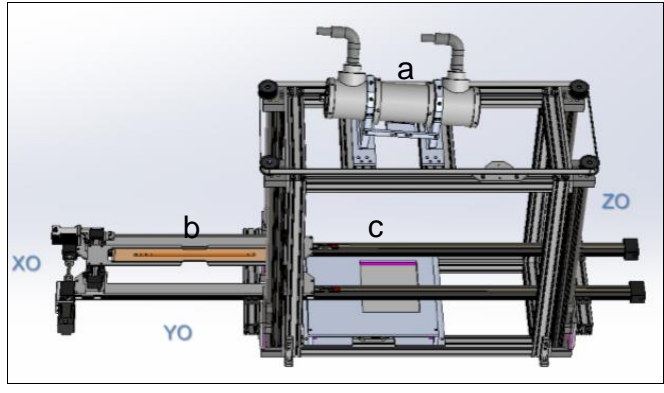

a: Tabung Sinar-X; b: Meja objek uji; c: Flat panel detector

Gambar 1. Posisi alat (sisi operator) ${ }^{[4]}$

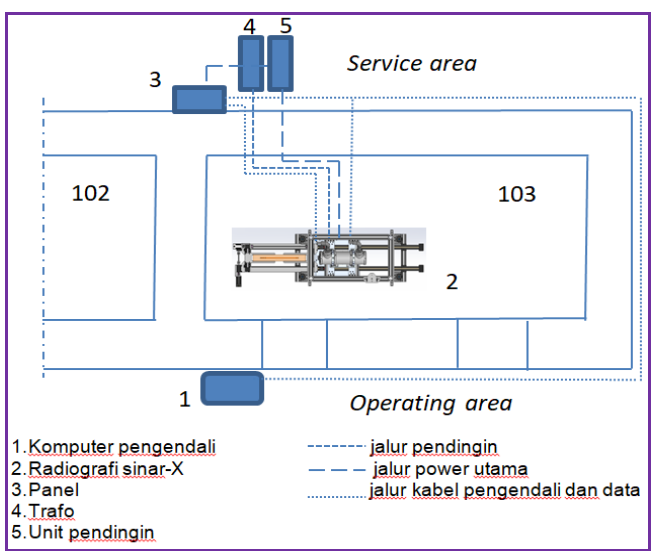

Gambar 2. Sketsa instalasi Radiografi Sinar-X di hot cell 103.

\section{HASIL DAN PEMBAHASAN}

Instalasi keseluruhan sistem radiografi sinar-X sudah terpasang di hot cell 103 IRM (Gambar 1 dan 2) dan sudah berhasil dilakukan uji fungsi dengan PEB teriradiasi (Tabel 1). Peralatan utama sistem radiografi sinar- $X$ terpasang di dalam hot cell 103 (Gambar 1). Posisi tabung sinar- $X$ terpasang pada bagian atas, flat panel detector pada bagian bawah sedangkan posisi tempat objek uji (meja objek uji) diantara tabung sinar-X dan flat panel detector. Sketsa keseluruhan sistem Radiografi Sinar-X di hot cell 103 dapat dilihat pada Gambar 2. Sistem pendukung seperti unit trafo, pendingin dan panel terpasang di service area, sedangkan unit pengendali berupa komputer, terpasang di operating area.

\section{Spesifikasi utama alat ${ }^{[4]}$}

- beban maksimum pada meja penempatan objek uji: $25 \mathrm{~kg}$

- arah gerak ke arah lebar (transversal) meja objek uji: $50 \mathrm{~mm}$

- arah gerak ke arah panjang (longitudinal) objek uji: $1.000 \mathrm{~mm}$

- tabung sinar-X, Volt: 20-320 kV (dapat diatur); ukuran fokus: 0,4 / 1 $\mathrm{mm}$

- area detektor dengan resolusi tinggi: 24.9 x $30.2 \mathrm{~cm}^{2}$; resolusi/ pitch: 139 $\mu \mathrm{m}, 1092 \times 2176$ pixels; cakupan energi: 40-320 kV (termasuk external shielding); frame rate: $9 \mathrm{fps}(1 \times 1), 30$ fps (2x2).

Sistem sinar- $X$ menggunakan dua generator tegangan tinggi, unit kendali dan unit pendingin yang menggunakan oli. Tegangan tinggi diukur secara langsung pada setiap generator tegangan tinggi. Unit kendali menggunakan mikroprosesor yang terintegrasi dan dirancang dengan faktor ergonomik yang baik sehingga nyaman untuk dioperasikan dan dengan keandalan operasional yang baik. Stabilitas parameter sinar- $X$ yang sangat tinggi ( $k \mathrm{~V}, \mathrm{~mA})$ dengan melakukan pemantauan terus-menerus dari setpoint dan nilai aktual. Nilai perbandingan operasi yang konstan dengan nilai maksimum sistem, untuk melindungi sistem terhadap kelebihan beban. Frekuensi operasi tinggi $40 \mathrm{kHz}$ untuk pembangkit tegangan tinggi dan pemanasan filamen memungkinkan stabilitas yang sangat baik untuk jangka pendek, jangka menengah, jangka panjang, dan juga dengan fluktuasi minimal.

\section{Struktur antarmuka pengguna}

Pada pengoperasian Radiografi Sinar-X, kendali operasi dilakukan melalui layar komputer dan tampilan 
pada layar seperti pada Gambar 5. Area variasi parameter pada sebelah kanan. antarmuka pengguna dibagi tiga yaitu: Perbedaan antarmuka pengguna muncul area tombol menu pada sebelah kiri, area kerja di tengah dan area berbagai di layar tergantung pada menu yang dipilih.

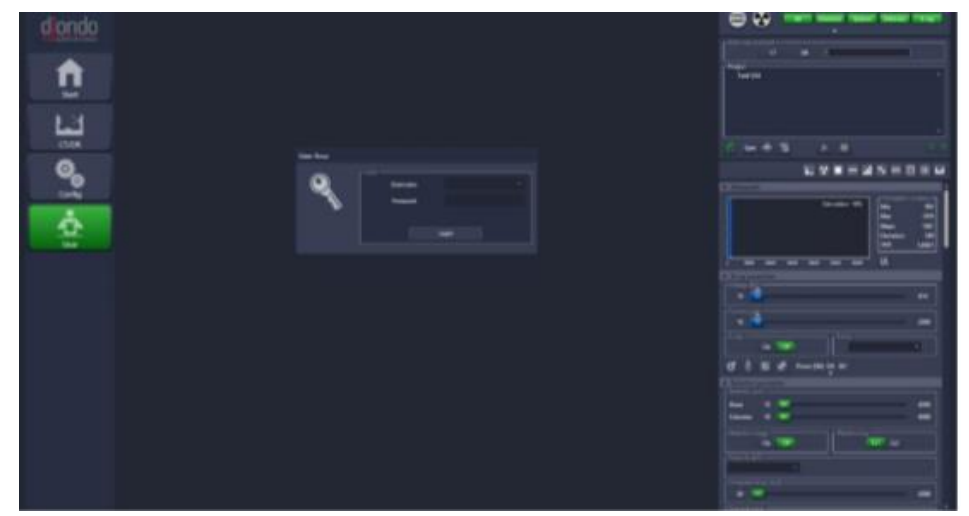

Area antarmuka ke pengguna

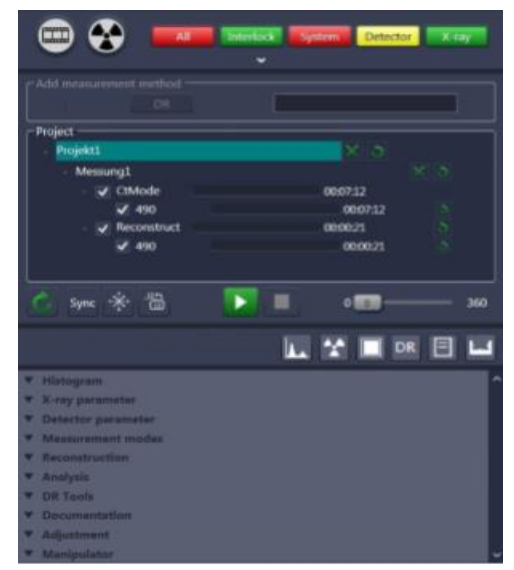

Menu parameter

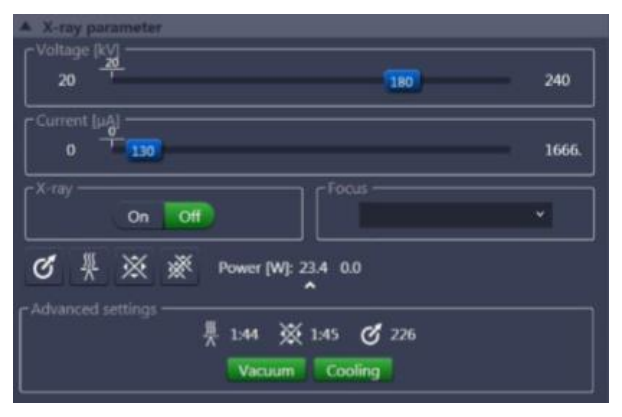

Menu parameter sinar- $X$

Gambar 5. Tampilan antarmuka pada layar komputer 
Tabel 1: Parameter operasi dengan objek uji PEB pasca iradiasi

\begin{tabular}{ll|l|}
\hline Parameter x-ray & \multicolumn{2}{l}{} \\
\hline Voltage $(\mathrm{kV})$ & 200.000 & \\
Current $(\mu \mathrm{A})$ & 800.000 & \\
Power $(\mathrm{W})$ & 160.000 & \\
Focus & Foc0 & \\
\hline Parameter detektor & & \\
\hline Colums (Px) & 1816 & \\
Colums $(\mathrm{mm})$ & 252.424 & \\
Rows $(\mathrm{Px})$ & 1508 & \\
Rows $(\mathrm{mm})$ & 209.612 & \\
Pixelbinning & $1: 1$ & \\
Integration time (ms) & 130 & \\
Framebinning & 70 & \\
Capacity $(\mathrm{pF})$ & $1 \times 12 \mathrm{pF} \mathrm{VG1}$ & \\
Pitch (mm) & 0.139 & \\
Filter & Al1,00 mm & \\
\hline
\end{tabular}

\section{Uji fungsi}

Hasil uji fungsi berupa digital radiograf dengan menggunakan $\mathrm{PEB}$ teriradiasi dan parameter operasi disajikan pada Tabel 1. Jarak tepi batas

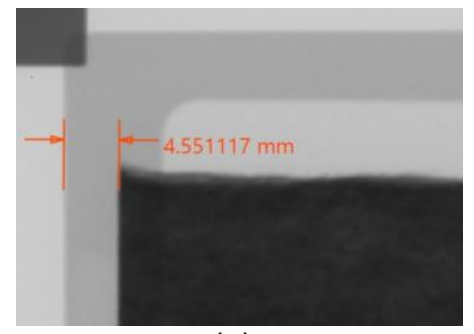

(a) antara cladding dan meat dapat terlihat dengan jelas. Dimensi lebar PEB serta lebar tepi meat ke pelat cladding dari objek uji berupa PEB non-iradiasi juga diukur, yang disajikan pada Gambar 6 .

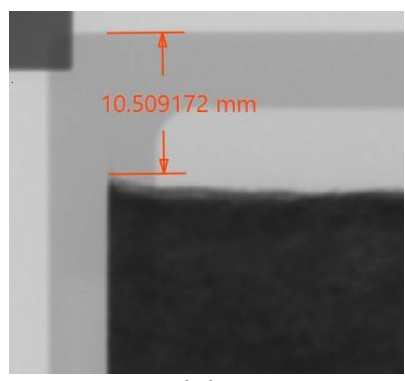

(b)

Gambar 6 (a) dan (b). Jarak tepi meat-cladding

Hasil radiograf berupa cacat (artifisial) disajikan pada Gambar 8 dengan paremeter utama; keV: $200 \mathrm{kV}$, arus listrik: $820 \mu \mathrm{A}$, integration time: $130 \mathrm{~ms}$, Focus: 0 (0.4 mm).
Pada kegiatan ini disajikan ukuran dari cacat dan dimensi cacat terkecil yang dapat ditunjukkan pada radiografnya perlu dioptimumkan sehingga lebih meyakinkan pada saat digunakan pada uji pasca iradiasi yang sesungguhnya. 


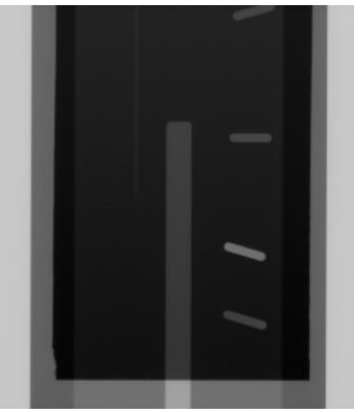

Gambar 7. Visualisasi cacat artifisial pada sampel Al (non-iradiasi)

Hasil dengan objek uji berupa short pin PWR-fuel (non iradiasi), disajikan pada Gambar 8 dan 9. Pada bagian plenum masih cukup terlihat dengan jelas kondisi pegas, sementara pada Gambar 9, citra dari pellet masih belum begitu jelas.

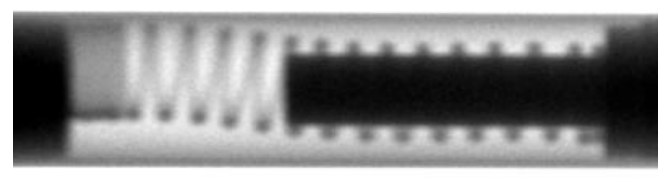

Gambar 8. Visualisasi dari material short pin PWR-fuel (non-iradiasi)

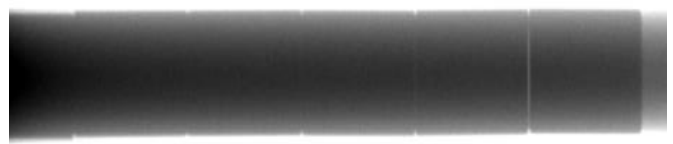

Gambar 9. Hasil citra short pin PWR-fuel bagian atas (non-iradiasi)

Hasil citra untuk short pin PWR-fuel yang diperoleh belum sempurna, terutama pada bagian pellet. Hal ini masih perlu studi dan eksperimen lebih lanjut untuk penentuan parameter operasi terutama terkait adanya permasalahan terkait perbedaan koefisien atenuasi sinar-X dari U $(49,08)$ dan $\mathrm{Zr}(2,47)$ seperti yang telah dilakukan oleh Grunauer, 2005[7].

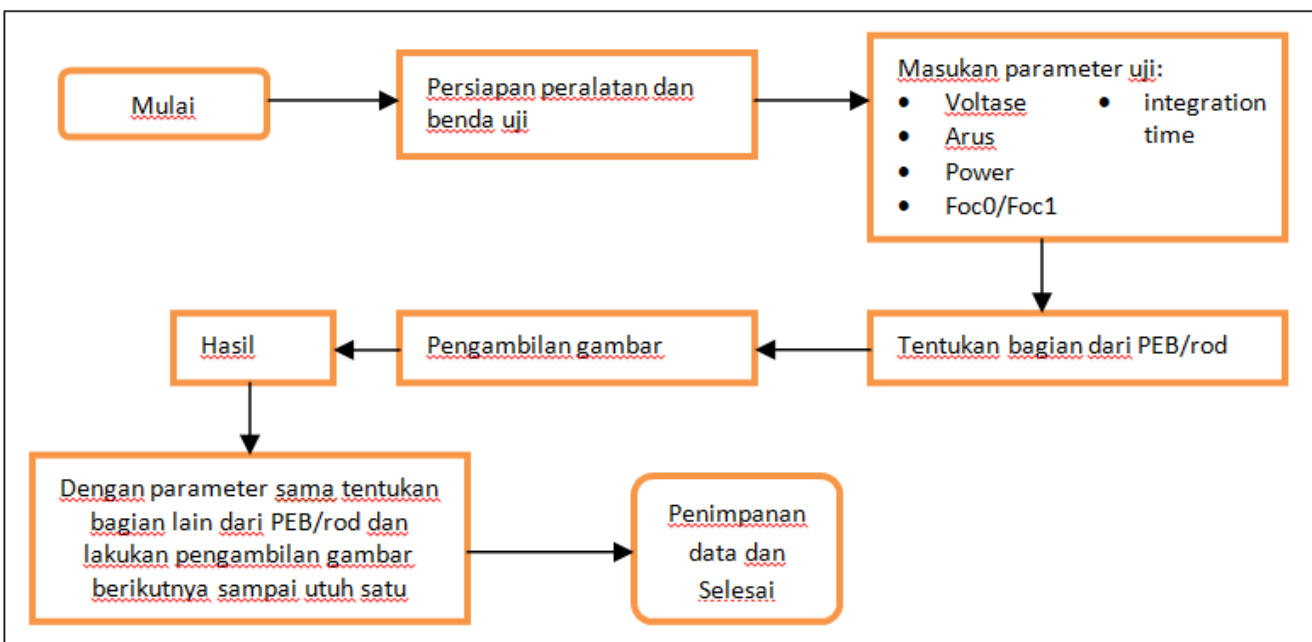

Gambar 10. Skema alur proses Radiografi Sinar-X untuk PEB [5]

Dari beberapa kali uji coba pepenggunaan Radiografi Sinar-X disajikan ngambilan gambar maka alur proses dari pada Gambar 10. Penentuan parameter 
utama seperti tegangan (voltase), arus, integration time, foc $0 / f o c 1$ sangat berpengaruh terhadap hasil dari digital radiograf. Disamping itu jarak antara objek dan tabung sinar- $X$ yang diatur secara manual dengan manipulator, juga sangat berpengaruh. Pengalaman dengan berbagai besaran paparan radiasi dari objek uji juga nanti dapat berpengaruh terhadap parameter operasi tersebut.

\section{KESIMPULAN}

Peralatan Radiografi Sinar-X yang telah diinstal di hot cell 103 IRM dan diuji fungsi menggunakan PEB teriradiasi dengan hasil optimum. Hasil tampilan citra untuk short pin PWR-fuel belum optimum masih perlu studi dan eksperimen lebih lanjut.

\section{SARAN}

Kondisi temperatur dan kelembaban udara di dalam hot cell 103 yang relatif masih tinggi perlu menjadi perhatian agar kondisi dan unjuk kerja alat radiografi sinar- $X$ di hot cell 103 dapat tetap terjaga dengan baik $\left(25^{\circ} \mathrm{C}\right.$ dan $70 \%$ [5]).

\section{UCAPAN TERIMAKASIH}

Penulis mengucapkan terimakasih kepada Tim Revitalisasi Hot Cell IRM yang sudah terlibat dalam kegiatan instalasi Radiografi Sinar-X di hot cell 103 IRM. Terima kasih Penulis juga kepada Ir. Sungkono MT sebagai Kepala Bidang Uji Radiometalurgi, Ir. Supardjo, MT dan Ir. Tri Yulianto yang telah menyediakan sampel untuk uji fungsi radiografi sinar-X. Terimakasih juga kepada semua rekan di PTBBN dan PRSG yang telah membantu kelancaran kegiatan pengadaan, instalasi dan uji fungsi Radiografi Sinar-X.

\section{DAFTAR PUSTAKA}

[1] Peraturan Kepala Batan Nomor 21 Tahun 2014, tentang Rincian Tugas Unit Kerja di Badan Tenaga Nuklir Nasional.

[2] Laporan Analisis Keselmatan (LAK) Instalasi Radiometalurgi (IRM), No. Dok: KK32 J09 001 Revisi : 1, 2012.

[3] V. Mozin et.al., Determining Plutonium Mass in Spent Fuel with Non-destructive Assay Techniques NGSI Research Overview and Update on NDA Techniques, Part II, IAEA-CN-184/137, LANL, Los Alamos, New Mexico, USA. Diunduh 04 Okt. 2019.

[4] Diondo X-ray systems and services, Operator Manual x-ray inspection system k4, Rev. 1.0, 27 November 2018.

[5] Antonio, Helmi, Sungkono, Rencana Penggunaan Radiografi Sinar-X untuk uji pasca iradiasi di Instalasi Radiometalurgi, Hasil-hasil

Penelitian EBN Tahun 2017 Pusat Teknologi Bahan Bakar Nuklir, ISSN 0854-5561, 2018.

[6] F.C. de Beer, Neutron- and X-ray radiography/tomography: non-destructive analytical tools for the characterization of nuclear materials, The Journal of The Southern African Institute of Mining and Metallurgy volume 115 October 2015. http://dx.doi.org/ 10.17159/ 24119717/2015/v115n10a3, diunduh 1 Oktober 2019.

[7] Standar Operasional Prosedur, "Pengoperasian Radiografi Sinar-X di Hot cell 103 IRM," nomor: 017.003/BN 02 06/ BBN.3.2, Februari 2019. 